\title{
Exploring the degree of trawling disturbance by the analysis of benthic communities ranging from a heavily exploited fishing ground to an undisturbed area in the NW Mediterranean
}

\author{
SILVIA DE JUAN, MONTSERRAT DEMESTRE and PILAR SÁNCHEZ \\ Institut de Ciències del Mar, ICM-CSIC, Passeig Marítim de la Barceloneta 37-49, 08003, Barcelona, Spain. \\ E-mail: sdejuan@icm.csic.es
}

\begin{abstract}
SUMMARY: This study focuses on 4 sites in the northwestern Mediterranean to investigate the response of benthic fauna across a gradient of trawling impact. One site was located in a heavily exploited fishing ground. The second site was enclosed in the fishing ground but had not been trawled in twenty years. The third site was located adjacent to a marine protected area and was subjected to occasional trawling. The fourth site was located inside the marine protected area, where trawling was banned thirty years ago. Side-scan sonar records of trawl marks on the seabed confirmed the gradient of trawling intensity. We investigated the response of benthic fauna to trawling disturbance at the mesoscale of a fishing ground. We compared the observed patterns of abundance, biomass, diversity and community structure for epifauna and infauna with responses predicted from previous studies. Results showed that those communities less impacted by trawling sustained more biogenically habitat-structured communities (e.g. more abundance of sessile suspension feeders at the less disturbed sites against higher dominance of small invertebrates at the disturbed site). Moreover, these results confirm the benefits of restricting trawling activities for benthic communities, with marine reserves as the paradigm for the conservation of Mediterranean fishing grounds.
\end{abstract}

Keywords: benthos, community composition, ecosystem management, fishing, marine reserves, Mediterranean Sea.

RESUMEN: ANÁLISIS DEL GRADO DE PERTURBACIÓN OCASIONADO POR LA PESCA DE ARRASTRE CONSIDERANDO COMUNIDADES BENTÓNICAS DE CALADEROS FUERTEMENTE EXPLOTADOS EN ÁREAS PROTEGIDAS. - El presente estudio se centra en 4 áreas del noroeste mediterráneo para investigar la respuesta de la fauna bentónica considerando un gradiente de niveles de impacto provocado por la pesca de arrastre. Un área se sitúa en un caladero fuertemente explotado. La segunda se halla en el interior del caladero pero no ha sido explotada en 20 años. La tercera está situada en una zona adyacente a un área marina protegida sujeta ocasionalmente a la pesca de arrastre. Finalmente, la cuarta se sitúa en el interior del área marina protegida donde la pesca de arrastre está prohibida hace treinta años. Mediante las marcas de arrastre del fondo obtenidas con el sónar de barrido lateral se pueden confirmar los gradientes de intensidad de pesca de arrastre. Se analiza la respuesta observada de la fauna bentónica a la pesca de arrastre a mesoescala de un calador de pesca, comparando los patrones de abundancia, biomasa, diversidad y estructura de la comunidad de la epifauna y la infauna, comparándola con respuestas ya predichas en previos estudios. En general, los resultados mostraron que las comunidades menos impactadas por el arrastre están constituidas por comunidades más estructuradas (por ejemplo, más abundancia de filtradores suspensívoros sésiles en las zonas menos perturbadas frente una mayor dominancia de pequeños invertebrados en las zonas perturbadas). Al mismo tiempo, estos resultados confirman los beneficios de restringir las actividades de pesca de arrastre para las comunidades bentónicas, siendo las reservas marinas el paradigma para la conservación de los caladeros de pesca.

Palabras clave: bentos, composición de la comunidad, gestión ecosistémica, pesca, reservas marinas, mar Mediterráneo. 


\section{INTRODUCTION}

Traditional management of Mediterranean otter-trawl fisheries has been mainly based on effort control (e.g. limited by fishing days, seasonal closures and horsepower), the establishment of a minimum commercial size for most target species and the restriction of the minimum trawling depth (generally established at $50 \mathrm{~m}$ or within 3 miles of the coast) (Papaconstantinou and Farrugio, 2000; Cacaud, 2005; Demestre et al., 2008). Recently, trawling was banned in areas deeper than $1000 \mathrm{~m}$ to protect the vulnerable deep seas (recommendation GFCM/2005/1), so trawling fleets fish soft bottoms on the continental shelf and slope intensively (Sanchez-Lizaso and Lleonart, 2002). Many of these habitats might be essential fish habitats that are important for refuge, feeding, growth and recruitment of commercial species, or sensitive habitats that support highly vulnerable organisms which are often of interest because of their rarity, including Crinoidea and Maërl beds in the Mediterranean (Ardizzone, 2006). The value of these habitats and the threat of intensive disturbance emphasize the importance of adopting an ecosystem approach to fisheries in order to simultaneously manage both target species and non-commercial organisms and habitats (Browman and Stergiou, 2004; Thrush and Dayton, 2010).

Numerous studies have demonstrated that towed fishing gears have strong negative consequences for ecosystems (e.g. Thrush et al., 1998; Sanchez et al., 2000; Smith et al., 2000; Jennings et al., 2002; Gray et al., 2006; Kaiser et al., 2006). Trawling scars the seabed and damages benthic fauna, altering the structure and composition of communities (Queirós et al., 2006; Tillin et al., 2006; de Juan et al., 2007). The fisheries in the Mediterranean also have a high by-catch rate: $30-$ $40 \%$ of the total catch are discarded with important impacts on habitats and benthic communities associated with organic deposition (Machias et al., 2001; Sanchez et al., 2007). However, many studies are hampered by sampling over limited spatial and temporal scales, which restrict the extent to which they match the impact of commercial trawling (Thrush et al., 1998). The lack of control areas also limits the direct definition of ecosystem responses (Hewitt et al., 2001), and in this study areas subjected to different trawling intensities were surveyed to investigate ecosystem effects based on a disturbance gradient across areas. Continental shelves have been exploited since historical times, decreasing the spatial refuge with the increasing advances in gear technology (Dayton et al., 1995). This is particularly evident in the Mediterranean, which has narrow continental shelves where every area that can be fished has been fished (Pipitone et al., 2000; de Juan et al., 2009). Consequently, the detection of areas subjected to different levels of trawling intensity gives us the best opportunity to study the effects of commercial trawling on benthic communities and habitats.

The present study aims to describe benthic community patterns of 4 soft-bottom sites located in the northwestern Mediterranean that are subjected to different trawling intensities, from a heavily trawled area to a protected area. We assume that a wider range of areas subjected to different trawling intensities must be analysed in order to draw consistent conclusions on the direct relation between disturbance and community responses. However, the comparison of these 4 sites allows us to investigate emerging patterns of community response in different fishing effort scenarios, where a previous study (see de Juan et al., 2009) demonstrated differences in the biological traits composition of epibenthic communities at these sites. Research needs to focus on drawing sound conclusions on the effects of trawling on ecosystems despite the difficulty of generalizing patterns due to the spatial and temporal natural variability (Hewitt et al., 2001). Most studies on the effects of commercial trawling on ecosystems have been carried out in the North Sea and North Atlantic (see Kaiser et al., 2006). Therefore, research on this topic needs to focus on generalizing ecosystem responses to trawling disturbance by studying other locations, such as the Mediterranean temperate waters, and the knowledge obtained should be used to draw up and implement an ecosystem-based fisheries management (Frid et al., 2005).

Aiming to understand the effects of fishing intensity on the structure of benthic communities, we consider several potential responses that can occur on the basis of the main predicted effects of trawling apparent from the numerous scientific papers on this subject (e.g. Thrush and Dayton, 2002; Bremner et al., 2003; Bremner and Frid, 2005; Kaiser et al., 2006): 1) a significant reduction in abundance and number of species due to the removal of the organisms vulnerable to trawling; 2) a significant reduction in the overall biomass due to the elimination of the large and slow-growing organisms; and 3) a shift towards a community dominated by small and mobile invertebrates, scavengers and epifaunal predators. When there is no observed response to trawling effort, we expect differences to mainly result from habitat variability and location effects. The final aim of the study was to investigate differences between intensively fished sites and less fished sites at the benthic community level in order to consider the benefits of trawling restrictions for ecosystems.

\section{MATERIALS AND METHODS}

\section{Study areas}

The 4 sites were located between 45 and $60 \mathrm{~m}$ depth on the NW Mediterranean continental shelf: 2 on the Ebro Delta shelf and 2 associated with the Medes Islands Marine Protected Area (MPA) (Fig. 1). The area off the Ebro Delta is operated by the trawling fleet from Sant Carles de la Ràpita harbour, but includes a small area $\left(2.7 \mathrm{~km}^{2}\right)$ that remains undisturbed due to the debris of an oil platform exploited 20 years ago. 


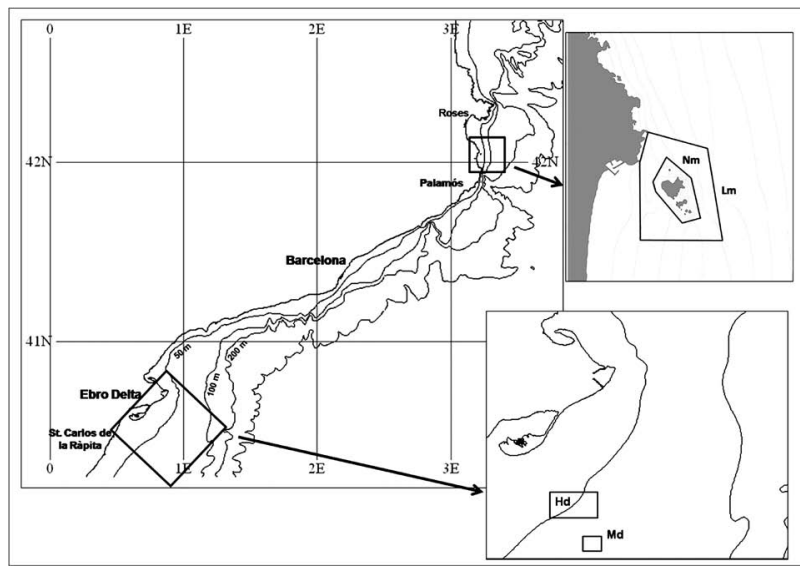

FIG. 1. - Map of the study area in the NW Mediterranean: Hd and Md off the Ebro Delta in the south of the Catalonian region (Spain), and $\mathrm{Lm}$ and $\mathrm{Nm}$ in the north at the Medes Islands MPA (Spain).

One study site was located within the fishing ground (Hd) and the second site was inside the undisturbed area $(\mathrm{Md})$. The Medes Islands MPA was established in 1983, prohibiting all trawling activities, but trawlers from Roses and Palamos harbours occasionally fish adjacent to the MPA. The third study site was located inside the MPA (Nm) and the fourth site was outside the MPA (Lm). These 4 sites were characterized by softbottoms (99\% mud at the 2 Ebro Delta sites and coastal detritic mud at the Medes sites) with very similar environmental variables (average near-bottom temperature $14-15^{\circ} \mathrm{C}$ in spring and early summer), and under the influence of 2 rivers (the River Ebro in the south and the River Ter in the north). Fishing intensity at the Delta fishing ground was estimated as fishing hours per month, based on auction records and interviews with the local fishermen. This small-scale estimation of fishing effort is possible as trawlers return every day to the same harbour, where they register daily catches and fishing hours (Sartor et al., 2007). Additionally, side-scan sonar (SSS) surveys at each site registered the density of trawl marks on the seabed that could be contrasted with the fishing intensity (Demestre, 2006; Sartor et al., 2007). The SSS images of each study area (an example is included in Fig. 2a) were used to identify the trawl tracks marked on the soft sediments. These images are simplified by drawings of the density of trawl marks in the study area to subsequently estimate trawling intensity (Friedlander et al., 1999). The SSS records and benthic samples were obtained in each area during the same experimental cruise.

\section{Benthic communities}

Epibenthic fauna was surveyed with a surface dredge similar to a $2-\mathrm{m}$ beam-trawl, with a $2 \times 40-\mathrm{cm}$ iron-framed aperture and a $10-\mathrm{mm}$ cod-end. At the 2 Ebro Delta sites a total of 6 replicate epifaunal samples were randomly collected from late June to early July 2003; 5 samples were randomly chosen to avoid an unbalanced design. In the Medes area 5 replicate epifaunal samples were randomly collected at each site in May 2007. The same sampling protocol was applied at the 4 sites, and each replicate consisted of a 15-minute tow at $3 \mathrm{kn}$ (established as the minimum sampling size after the species accumulation curve). To ensure continuous contact of the gear with the seabed, a side-scan sonar was placed on the iron frame of the dredge. The infaunal organisms were collected with a $0.1-\mathrm{m}^{2}$ van Veen grab at 5 stations randomly located at each of the 4 sites (in the Ebro Delta area in June 2003; in the Medes area in May 2007). Five grabs were collected at each station in order to obtain the minimum sampling size, and sediment samples were sieved over $1 \mathrm{~mm}$ to retain the macrofauna.

The collected organisms were identified to species level for epifauna and to family level for infauna. Abundance was recorded as number of individuals per taxon, and epifaunal biomass as wet weight $(0.1 \mathrm{~g})$. The epifaunal data was standardized to a surface of $1000 \mathrm{~m}^{2}$ and the infaunal data to $1 \mathrm{~m}^{2}$.

\section{Data analyses}

Several variables of the benthic community were analysed: total abundance of infauna and epifauna, biomass of epifauna, percentage of abundance of the main taxonomical groups, Margalef species richness (S-1/ LnN) and Shannon diversity (H' Ln). A 1-way analysis of variance (ANOVA, SPSS v17) was used to test differences in univariate variables between the 4 sites. The statistical assumptions that underline the analysis of variance were tested using the Kolmogorov-Smirnov test of normality, and Levene's test of homogeneity of error variances. When the normality assumptions were not met, a $\log _{10}$ transformation was applied to achieve a normal distribution of data. A Bonferroni post-hoc comparison test was applied to detect the significant differences between pairs of sites.

Differences in relative species abundance and species composition were studied with multivariate analyses (PRIMER v.6; Clarke and Warwick, 1994). The analyses were done with the epifauna/infauna abundance data from the 5 replicates at the 4 sites, after a square root transformation of data to reduce the influence of dominant species. Principal coordinates analysis (PCO), based on the resemblance matrix after Bray-Curtis similarity, was calculated for epifauna and infauna to determine the spatial ordination of samples, and then to determine the Spearman correlation index of species abundance with the obtained ordination of samples. The comparison of the accumulative abundance and biomass curves $(\mathrm{ABC})$ was determined for the epifauna as a measure of community dominance. The W statistic (comprised between -1 and 1) is a measure of dominance with higher species dominance represented by lower values (Clarke, 1990). Differences between $\mathrm{W}$ values at the 4 sites were tested with a paired samples $t$ test. 

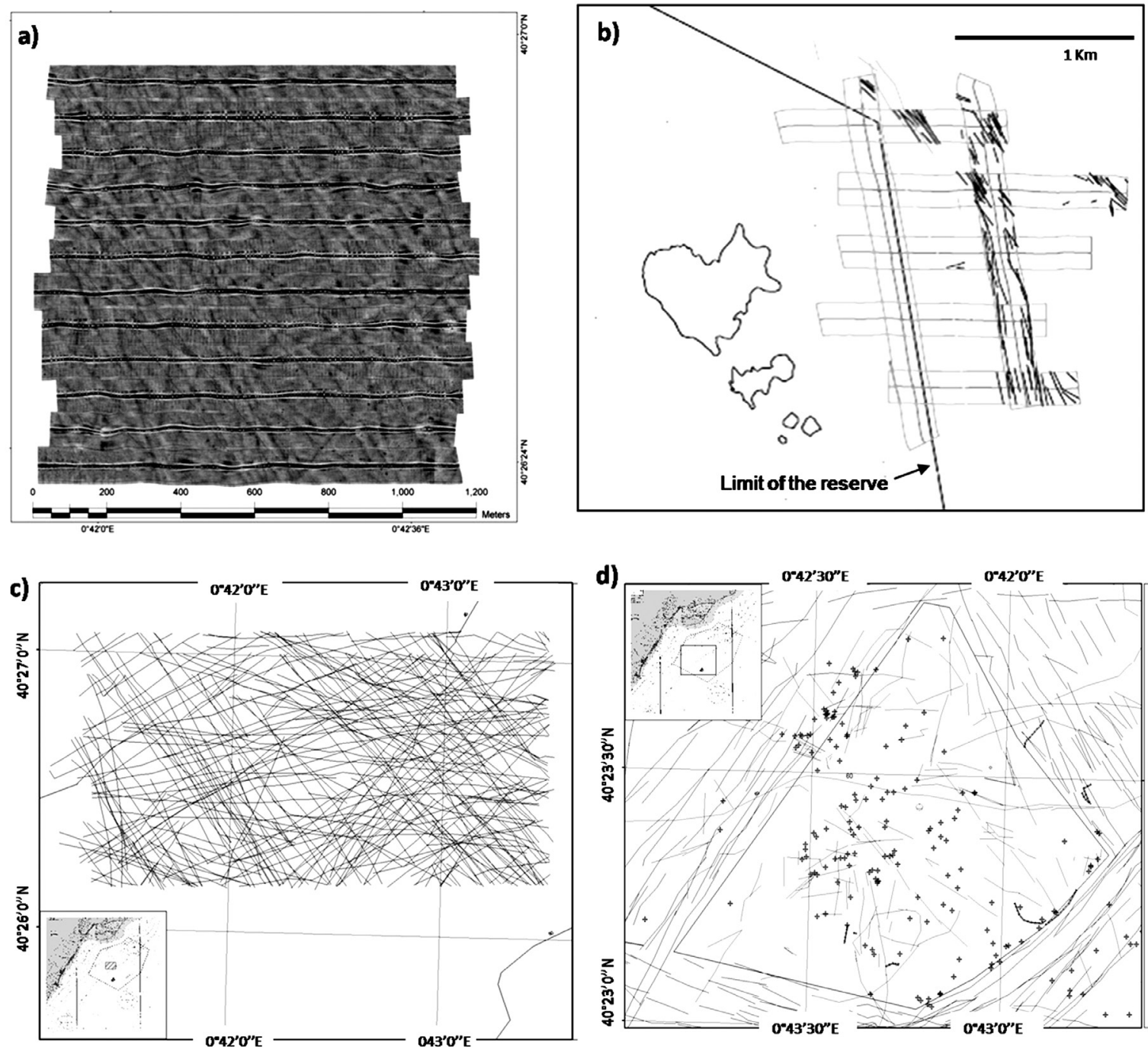

FIG. 2. - Side-scan sonar (SSS) results: a) overlapped images of the SSS from the Ebro delta fishing ground. The representation of the trawl marks at b) Lm and Nm sites at the Medes Islands area, c) Hd site in the Ebro Delta fishing ground, and d) the untrawled area at the Ebro Delta $\left(\mathrm{Md}, 2.7 \mathrm{~km}^{2}\right)$. Continuous lines in $\mathrm{b}, \mathrm{c}$ and $\mathrm{d}$ represent the trawl marks on the seabed. Dots at Md represent the remains of the exploited oil platform. Lm-Nm image includes the transect followed by the SSS, inside and outside the MPA.

\section{RESULTS}

\section{Fishing pressure}

Four levels of fishing pressure were estimated based on the density of trawl marks on the seabed obtained with the SSS (Fig. 2b, c and d). The trawl marks can last more than 1 year on muddy bottoms (Palanques et al., 2001) and allow the disturbance at a specific location to be estimated. The images obtained with SSS confirm the effort intensity considered for the 4 sites. The highest level of fishing pressure was found at the site located within the fishing ground off the Ebro Delta area (Hd), which had a trawling activity of 6400 fishing hours per month in June 2003 (Demestre 2006) and a high density of trawl marks. The small undisturbed site in the Ebro Delta area (Md) is under the influence of the high trawling intensity from the surrounding fish- ing ground, which increases turbidity and might limit recovery (Allison et al., 1998; Palanques et al., 2001), so it was not considered to be totally protected from trawling. The site adjacent to the Medes Islands MPA $(\mathrm{Lm})$ is impacted by trawlers from 2 neighbouring ports that occasionally fish there on the way to deeper fishing grounds (fishermen's personal observation), so it is considered to have a low impact. The site inside the Medes MPA had no fishing effort (Nm).

\section{Epifaunal community}

No significant differences were detected for total epifaunal abundance, species richness and Shannon diversity between the 4 sites (Fig. 3; Table 1). Epifaunal biomass was significantly higher at $\mathrm{Nm}$ than at $\mathrm{Hd}$.

Overall, 57 epifaunal species were identified at $\mathrm{Hd}, 54$ at Md, 73 at $\mathrm{Lm}$ and 77 at Nm. Epifau- 

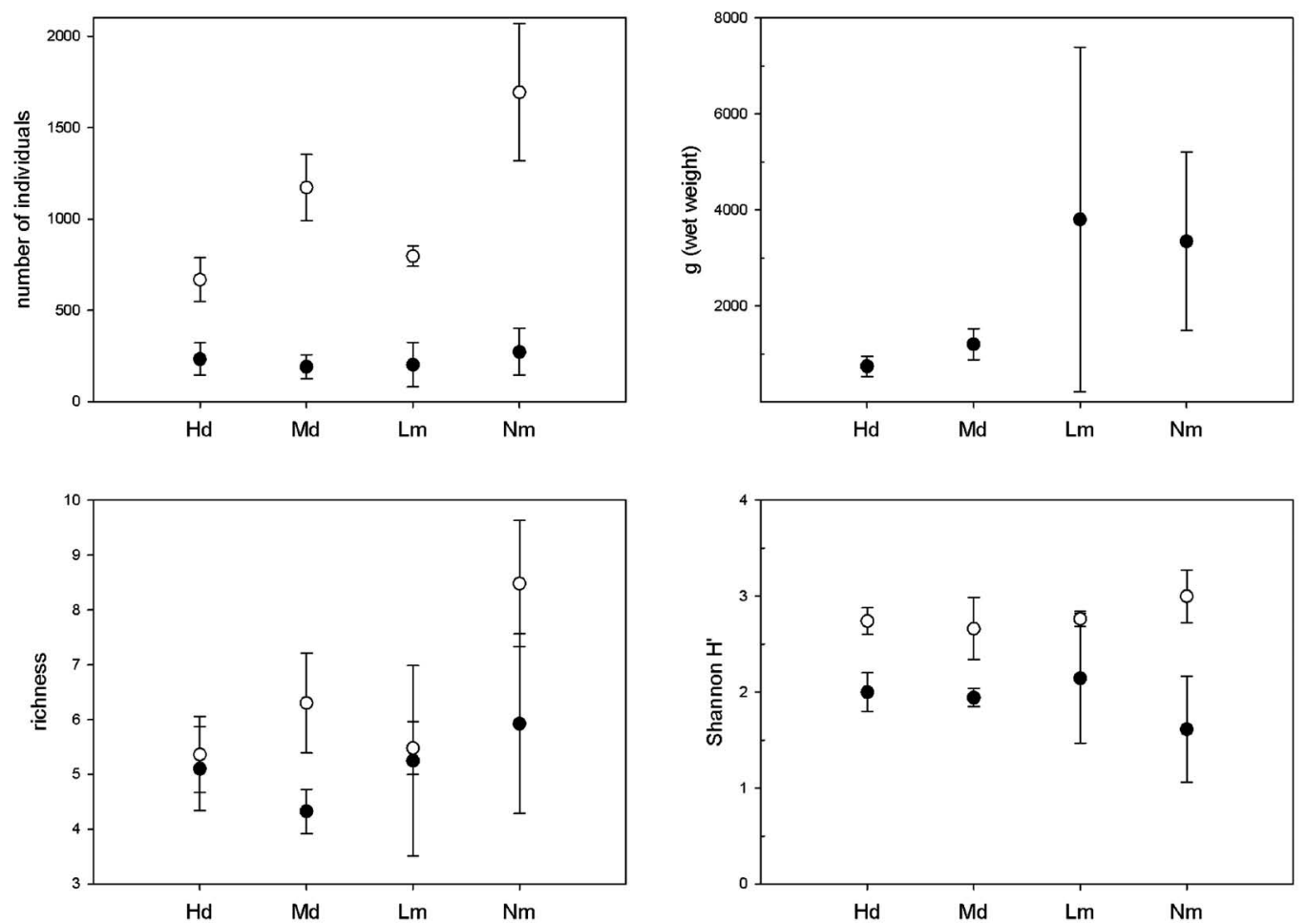

FIG. 3. - Mean and SD of epifaunal (black circles) and infaunal (open circles) total abundance, species richness and Shannon diversity, and epifauna biomass at the 4 sites.

nal abundance at $\mathrm{Hd}$ was dominated by Crustacea (45\%), Asteroidea (27\%) and Gastropoda (15\%). At Md Crustacea (51\%) and Asteroidea (30\%) were the dominant organisms, and Osteichthyia (fish) was the third most abundant group (11\%; fish abundance being higher at $\mathrm{Hd}$ and $\mathrm{Md}$ than at the other sites). At Hd and Md Asteroidea were more abundant than at $\mathrm{Lm}$ and $\mathrm{Nm}$ and bivalves were more abundant than at $\mathrm{Nm}$.
Crustacea abundance was highest at $\mathrm{Md}$ and lowest at $\mathrm{Nm}$. At Lm and Nm Cnidaria was the most abundant group (47\% and $82 \%$ respectively) and were more abundant than at $\mathrm{Hd}$ and $\mathrm{Md}$. Furthermore, at $\mathrm{Lm}$ Gastropoda (32\%) were significantly more abundant than at Md (Table 1).

The comparison of the accumulative abundance and biomass curves (ABC) for epifauna (Fig. 4) shows

TABLE 1. - a) ANOVA table showing the significance of differences in epifaunal and infaunal variables in the 4 study areas. Significant $P$-values in bold. b) Bonferroni's post-hoc test, this table includes the variables that are significantly different between 2 locations (N, abundance; B, biomass; S, richness; inf-, infauna; epi-, epifauna).

\begin{tabular}{|c|c|c|c|c|c|}
\hline a) Epifauna & $\mathrm{F}$ & $P(\alpha=0.5)$ & Infauna & $\mathrm{F}$ & $\mathrm{P}(\alpha=0.5)$ \\
\hline Abundance & 0.62 & 0.61 & Abundance & 20.24 & $<0.001$ \\
\hline Biomass & 4.00 & 0.027 & Richness & 14.27 & $<0.001$ \\
\hline Richness & 1.49 & 0.25 & Shannon (H') & 2.1 & 0.145 \\
\hline Shannon (H') & 1.59 & 0.23 & Polychaeta & 17.9 & $<0.001$ \\
\hline Cnidaria & 25.4 & $<0.001$ & Crustacea & 18.8 & $<0.001$ \\
\hline Gastropoda & 4.9 & 0.014 & Bivalvia & 10.14 & $<0.001$ \\
\hline Bivalvia & 8.8 & 0.002 & Sipunculida & 18.3 & $<0.001$ \\
\hline Crustacea & 42.8 & $<0.001$ & & & \\
\hline Fish & 22.4 & $<0.001$ & & & \\
\hline Asteroidea & 46.9 & $<0.001$ & & & \\
\hline b) & & & Md & & \\
\hline
\end{tabular}

Md Inf-N; epi-Crustacea; Polychaeta

Lm Cnidaria; Asteroidea; Fish; inf-Crustacea

$\mathrm{Nm}$

Epi-B; inf-N; inf-S; Cnidaria; Asteroidea; epi-Bivalvia; Fish; inf-Bivalvia; Sipunculida
Inf-N; Cnidaria; epi-Crustacea; Fish;

epi-Gastropoda; Asteroidea;

Polychaeta; inf-Crustacea

Inf-S; Cnidaria; Fish; epi-Bivalvia; epi-Crustacea; Asteroidea; inf-Bivalvia; Polychaeta; inf-Crustacea; Sipunculida
Inf-N; inf-S inf-Crustacea; inf-Bivalvia; Sipunculida 

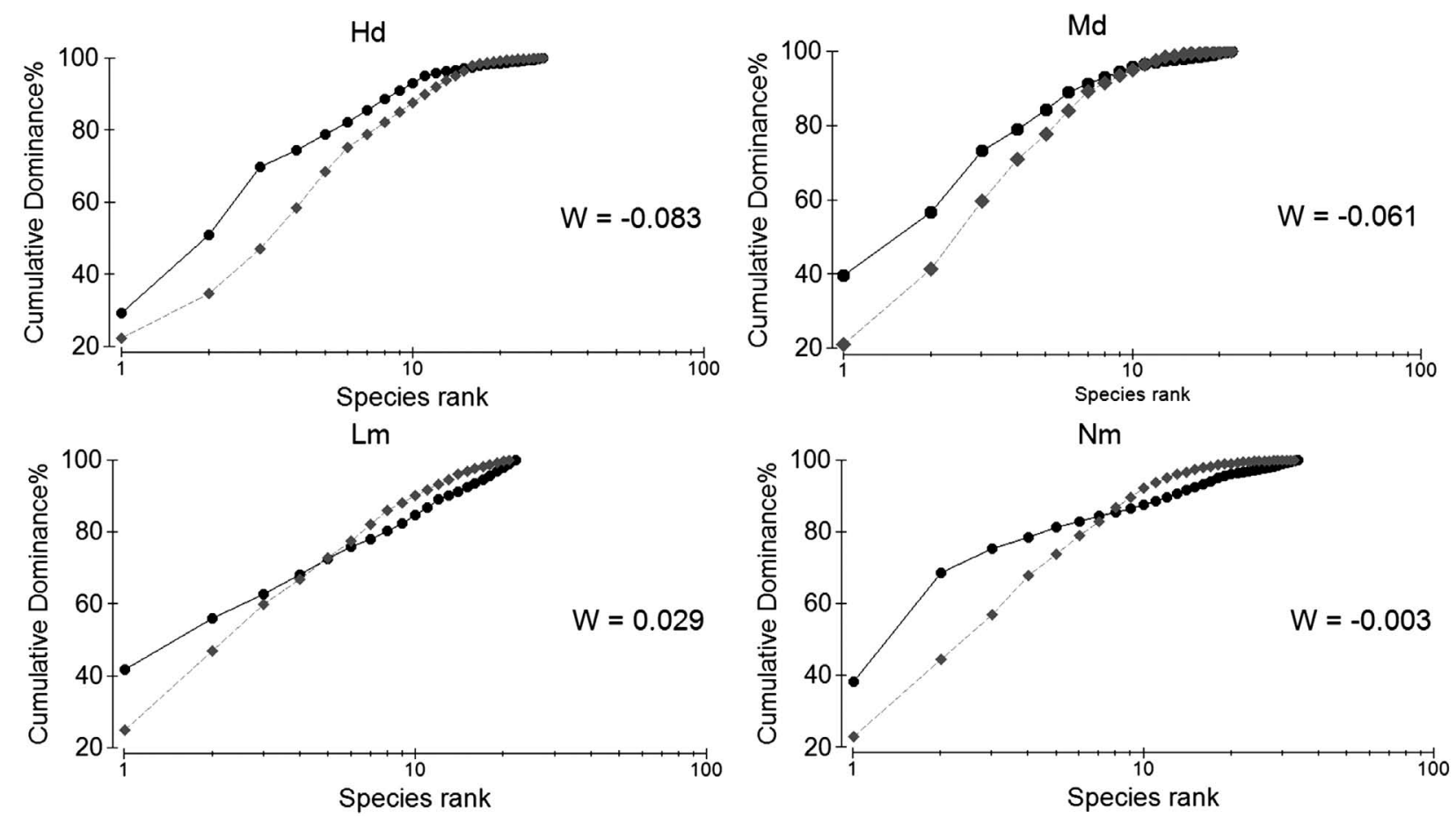

FIG. 4. - Abundance and biomass accumulative curves for epifaunal data at the 4 sites. Statistical value, $-1<\mathrm{W}>1$; Abundance, black circle; biomass, grey diamond.

an abundance curve above the biomass curve at the 4 sites, indicating that small fauna with few species dominated the total abundance: 5 species accounted for $80 \%$ of abundance at $\mathrm{Md}, 4$ species at $\mathrm{Hd}$ and $\mathrm{Nm}$, and 8 species at $\mathrm{Lm}$. Hd and Md held the lowest W values (Hd: -0.09 and Md -0.06), indicating an abundance curve well above the biomass curve, and Lm and $\mathrm{Nm}$ recorded 0.04 and -0.05 respectively. Hd and Md show a gross disturbance, whereas the other sites show a moderate disturbance because the curves intersect in these cases. The paired samples $t$ test detected significant differences between $\mathrm{Lm}$ and $\mathrm{Hd}(P=0.023)$ and $\mathrm{Md}(P=0.007)$.

Twenty-eight species had more than $1 \%$ of total abundance at at least 1 of the 4 sites. Many of these species were recorded at all 4 sites (e.g. Bolinus brandaris, Citharus linguatula, Pagurus excavatus, Goneplax rhomboides), whereas Cnidaria were mostly collected at $\mathrm{Lm}$ and $\mathrm{Nm}$, and Bivalvia were mostly collected at $\mathrm{Hd}$ and $\mathrm{Md}$. The PCO of epifaunal data explained $67.9 \%$ of variance by 2 components: PCO1 52.5\% and PCO2 $15.4 \%$ of variance (Fig. 5a). The first component differentiated $\mathrm{Hd}$ and $\mathrm{Md}$ from $\mathrm{Lm}$ and $\mathrm{Nm}$, and the second component separated $\mathrm{Hd}$ and $\mathrm{Lm}$ from $\mathrm{Md}$ and Nm. There were 13 epifaunal species with a Spearman correlation higher than 0.7 , with the ordination of samples: the fish Lesueurigobius friesii (PCO1: -0.78, PCO2: -0.13), the Crustacea Alpheus glaber (-0.83, -0.17), the Bivalvia Nucula nucleus $(-0.82,-0.18)$ and the Asteroidea Astropecten irregularis (-0.84, -0.23) were characteristic of Hd. The Bivalves Venus casina $(-0.76,-0.33)$ and Acanthocardia echinata (-0.57,
-0.45), the Crustacea G. rhomboides $(-0.69,-0.30)$ and the fish $C$. linguatula $(-0.75,-0.38)$ were characteristic of $\mathrm{Md}$. The Asteroidea Astropecten aranciacus (0.67, -0.02) were characteristic of Lm. Finally, Echinaster sepositus $(0.68,-0.43)$, the Cnidaria Alcyonium palmatum (0.82, -0.27), the fish Arnoglossus thori (0.64, -0.37), and the Polychaeta Aphrodita aculeata (0.76, -0.41) were characteristic of $\mathrm{Nm}$.

\section{Infaunal community}

Infaunal total abundance was significantly different across sites, abundance at $\mathrm{Md}$ and $\mathrm{Nm}$ being higher than abundance at $\mathrm{Hd}$ and Lm (Fig. 3; Table 1). Infaunal species richness was significantly higher at Nm, while the other sites were similar. Diversity based on Shannon index was similar at all sites.

The infaunal organisms were taxonomically identified to family level when possible and a total of 70 taxa were collected at $\mathrm{Hd}, 84$ at Md, 63 at Lm, and 105 at Nm. The most abundant group at all sites was Polychaeta: $72 \%$ at $\mathrm{Hd}, 74 \%$ at $\mathrm{Md}, 68 \%$ at $\mathrm{Lm}$ and $39 \%$ at $\mathrm{Nm}$ (a significantly higher abundance at Md, Table 1). The second most abundant group at $\mathrm{Hd}$ and Md was Crustacea, with $19 \%$ at $\mathrm{Hd}$ and $14 \%$ at $\mathrm{Md}$. Crustacea abundance was highest at Md and significantly lowest at $\mathrm{Lm}$. $\mathrm{Lm}$ recorded $6-8 \%$ dominance for each of the taxonomic groups: Crustacea, Bivalvia, Sipunculida and Cnidaria. These groups increased in dominance at Nm, with $26 \%$ of Sipunculida, $13 \%$ of Bivalvia (significantly higher at this site), $8 \%$ of Crustacea and $6 \%$ of Ophiuroidea. The category "other" includes groups 

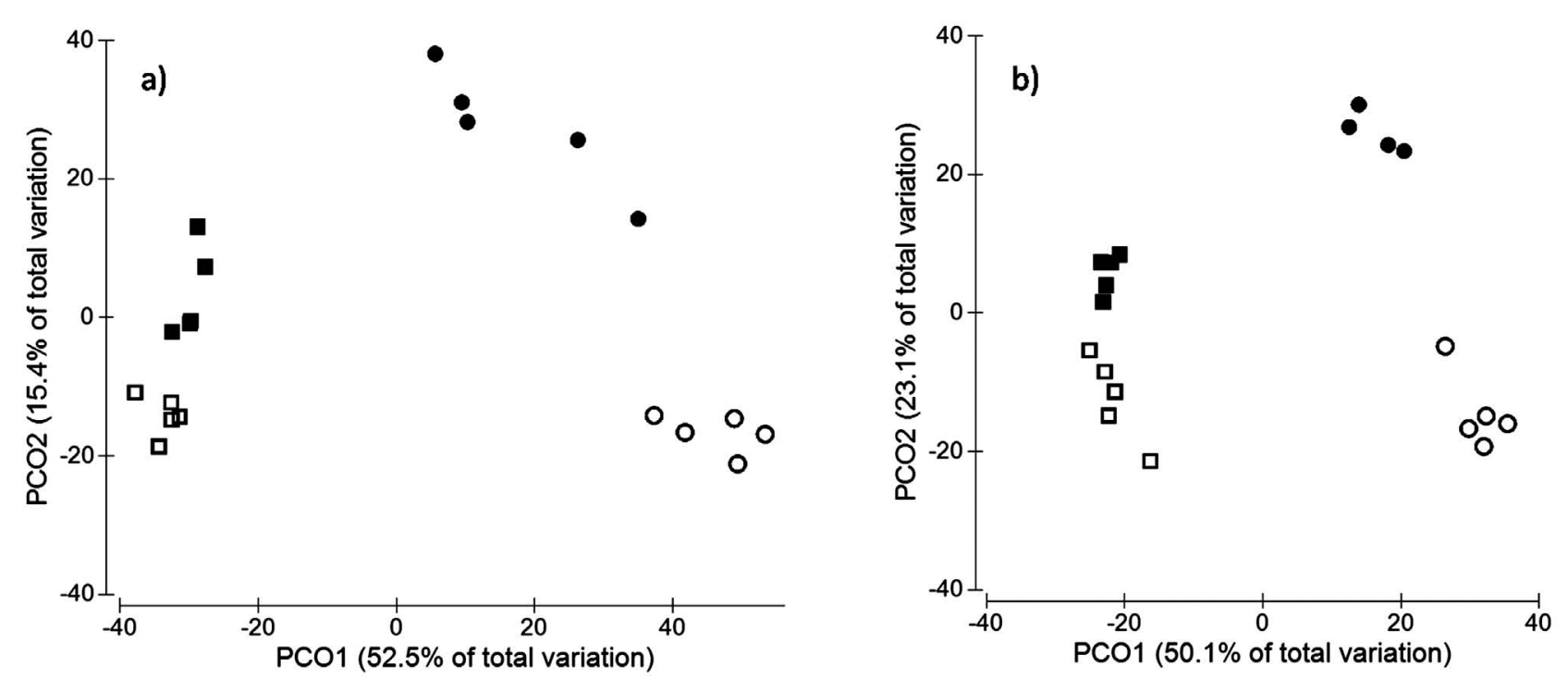

FIG. 5. - PCO ordination of samples at the 4 areas based on (a) epifaunal and (b) infaunal species abundance. Black square, Hd; open square, $\mathrm{Md}$; black circle, Lm; open circle, Nm.

collected in less than $5 \%$ abundance such as Holothuroidea, Ophiuroidea, Gastropoda, Scaphopoda, Echiurida, Nematoda, Turbelaria, Nemertini and Phoronidea.

Forty-one taxa had more than $1 \%$ of total abundance at at least 1 of the 4 sites. Many taxa were well represented at the 4 sites (e.g. the Polychaeta Cirratulidae, Lumbrineridae and Paraonidae, the Crustacea Ampeliscidae and the Bivalvia Nuculidae). The PCO of infaunal data explained $73.2 \%$ of variance by 2 components: PCO1 (50.1\%) and PCO2 (23.1\%) (Fig. $5 b)$. The ordination of samples followed the same pattern as for the epifaunal species: the first component differentiated $\mathrm{Lm}$ and $\mathrm{Nm}$ from $\mathrm{Hd}$ and $\mathrm{Md}$, and the second component differentiated $\mathrm{Hd}$ and $\mathrm{Lm}$ from $\mathrm{Md}$ and $\mathrm{Nm}$. The correlation of the ordination of samples with the species abundance highlighted 15 infaunal taxa holding a Spearman correlation index higher than 0.7. The Polychaeta Sternaspidae (PCO1, -0.72; PCO2, $0.11)$ was characteristic of Hd. The amphipoda Phoxocephalida (-0.88, -0.17) and Ampeliscidae (-0.23, -0.70), and the Polychaeta Ampharetidae (-0.62, -0.39) and Eunicidae $(-0.11,-0.68)$ were characteristic of Md. Sipunculida $(0.69,-0.47)$, the Bivalvia Veneridae $(0.69,-0.46)$, the Polychaeta Polyonidae $(0.70,-0.57)$, Syllidae (0.51, -0.68), Paralacidonida $(0.82,-0.11)$ and the holothurians Cucumaridae $(0.67,-0.52)$ were characteristic of Nm. The Polychaeta Nephtydae $(0.55$, $0.74)$ and Magelonidae $(0.43,0.76)$ were characteristic of Lm. The Bivalvia Nuculanidae $(0.76,-0.01)$, and the Polychaeta Glyceridae $(0.85,-0.02)$ were characteristic of $\mathrm{Lm}$ and $\mathrm{Nm}$.

\section{DISCUSSION}

The present study provided the opportunity to comparatively analyse a gradient of impacted communities based on knowledge acquired from previous studies (e.g. Thrush et al., 1998; Jennings et al., 2002; Kaiser et al., 2006) that have described common benthic community responses despite variability linked to environmental factors. This knowledge must now be applied to draw sound conclusions for the regulation of fishing pressure through an ecosystem-based management approach. The 4 sites were subjected to different effort intensities, which were qualitatively confirmed with the SSS. Though results may be influenced by sediment type, on muddy bottoms Palanques et al. (2001) detected trawl marks 1 year after disturbance, so this is a promising methodology for estimating fishing intensity in areas across a disturbance gradient (Krost et al., 1990; Friedlander et al., 1999). We emphasize the difficulty of defining an accurate gradient of trawling impact. While the extremes are obvious (high impact at Hd vs. no impact at $\mathrm{Nm}$ ), the indirect effects are difficult to classify: Md was not directly impacted by trawling, but this small area may be indirectly affected by the intensive trawling in the surrounding fishing ground, potentially limiting recovery by migration (Thrush et al., 2008) or negatively affecting the suspension feeder fauna due to the increase turbidity in the nearby fishing ground (Hill et al., 1999; Palanques et al., 2001). Site Lm was located adjacent to a MPA but was occasionally fished by the trawling fleets from Roses and Palamos harbours that fish here on the way to deeper fishing grounds or during adverse weather conditions. We might overcome this problem with a higher number of areas, as gradient designs are greatly strengthened as more sites up the gradient are included in the analysis (Ellis and Schneider, 1997). Results highlighted the need to improve the accuracy for estimating the level of fishing effort at a small scale, so as to detect the degree of disturbance on benthic communities from fishing grounds with a greater precision. 
Differences linked with habitat variability and distance between locations could be as important as differences due to fishing intensity. Nevertheless, within the context of difficult experimental design in natural communities linked to fishing grounds, we stress the importance of our results, which are consistent with patterns emerging from other trawling impact studies (e.g. Jennings and Kaiser, 1998; Auster and Langton, 1999; Thrush and Dayton, 2002). The first response predicted was a reduction in abundance and number of species with trawling intensity. Accordingly, the infaunal total abundance was higher in the areas with no fishing activity (Md and $\mathrm{Nm}$ ) and species richness was higher at Nm, in the MPA. Higher epifaunal biomass was collected at the Medes sites, Lm and Nm, agreeing with the second hypothesis of an increase in biomass with the reduction of trawling disturbance, and benefits of the MPA for nearby areas (Collie et al., 1997; Kenchington et al., 2001; Roberts et al., 2001). This trend was also observed in the abundance-biomass accumulative curves, which demonstrated dominance by small organisms that contributed little to community biomass in the most impacted areas (Jouffre and Inejih, 2005)

The third predicted response entailed a shift of species vulnerable to trawling to those capable of withstanding trawling (Bremner and Frid, 2005; de Juan et $a l .$, 2007). The epifaunal species tended to be present across sites, but differences in abundances of some species were detected between sites. Epifauna at the fishing ground, $\mathrm{Hd}$, was dominated by mobile and burrowing invertebrates (e.g. Astropecten irregularis and Alpheus glaber) that might have low vulnerability to trawling (Bremner et al., 2003; de Juan et al., 2007). The untrawled Md site showed higher abundance of bivalves and fish, suggesting that this area might act as a refuge zone within the heavily trawled area (Allison $e t$ al., 1998). At the Medes Lm and Nm site the dominant organisms were the sessile suspension feeder cnidarians, which are known to be very sensitive to trawling due to high mortality with direct contact with the gear (Veale et al., 2000) and due to collapse of their filtering system with the increasing turbidity caused by trawling (Hill et al., 1999). The infaunal community was dominated by polychaetes, with the lowest dominance occurring at Nm in the MPA, which in turn showed a higher abundance of groups such as sipunculids, bivalves and ophiurids. A benthic community dominated by polychaetes and other small fauna has been described as typical of muddy areas (Pearson, 2001; Ellingsen, 2002), as was found in our study. However, as these soft-bottoms have been exploited over decades, it is difficult to determine whether this is a consequence of historical disturbance or represents a fundamental characteristic of a muddy bottom community (Dayton et al., 1995). Otherwise, Smith et al. (2000), in a trawling impact experiment in the eastern Mediterranean, observed that Polychaeta, being the dominant organisms, were less impacted than Sipunculida or Echinodermata. In our study, the lower domi- nance of Polychaeta with higher abundance of other taxa in the no-trawling area indicates a more structured community in this area. Trawling induces the replacement of vulnerable organisms (e.g. sessile cnidarians, large echinoderms, bivalves) by organisms that can withstand the continuous impact of trawling (e.g. starfish, small swimming crabs, polychaetes). This shift might result in important changes in the functioning of the ecosystem due to reductions in suspension feeders, burrowing bivalves or large deposit feeders, which increase sediment and nutrient fluxes, or tube worms, which increase sediment stability (Widdicombe et al., 2000; Lohrer et al., 2004), with a consequent loss of ecosystem structure and function.

The fourth potential response implied that most differences were a product of regional variability. The epifaunal/infaunal taxonomic composition was similar at the closest sites (Ebro sites vs. Medes sites), reflected in the first PCO axis, and we highlight that many more sampling sites are needed to tease apart the effects of trawling and location. The epibenthic community in the Ebro area might be linked to a muddy environment (e.g. the invertebrates A. irregularis, T. communis, Venus casina, A. glaber are known to inhabit muddy areas). Nevertheless, some differences appear between the 2 Ebro sites, with higher abundance of bivalves and fish at the undisturbed site, and further recovery might be limited by intense trawling in the surroundings of this small area. The second component (explaining $15 \%$ of variance for epifauna and $23 \%$ for infauna) can represent fishing intensity effects by differentiating $\mathrm{Hd} / \mathrm{Lm}$ from $\mathrm{Md} / \mathrm{Nm}$. Infauna seems to better discriminate fishing intensity effects, which can be linked to the sedentary nature of these organisms. The more mobile epifauna probably requires larger undisturbed areas to allow protection of larval dispersal and adult migration. This is of great interest for the planning of protection measures such as MPAs (Stelzenmuller et al., 2007).

Some authors propose that areas closed to trawling can be considered as the only effective measure to protect habitat features (Auster, 2001), and these should thus be considered the main focus of an ecosystem approach to management (Browman and Stergiou, 2004). In agreement with this, our results suggest that areas free from trawling will be occupied by more structured communities (e.g. at the untrawled $\mathrm{Nm}$ we observed higher epifaunal biomass, dominance of Cnidarians and an infaunal community less dominated by Polychaeta). These communities can act as EFH and are important for the survival of many target and nontarget organisms. The small undisturbed area within the fishing ground showed a higher abundance of fish and bivalves and, in agreement with other studies (e.g. Collie et al., 1997; Pipitone et al., 2000; Duineveld et al., 2007; Rees et al., 2010), suggests the benefits of this untrawled area despite its small size.

MPAs have proven to be effective in fisheries rebuilding in adjacent areas around the world (Roberts 
et al., 2001). However, the use of MPAs to protect habitats from fishing is not a common measure. In the Mediterranean, most marine reserves established to protect ecosystems from anthropogenic impacts have been sited in intrinsically ecological rich places, resulting in a very heterogeneous pool of small reserves along the coast (Ojeda-Martínez et al., 2009), with few exceptions that include soft bottoms on continental shelves (e.g. Pipitone et al. 2000; Dimech et al., 2008). Soft bottoms have been ignored in the issue of ecosystem conservation and, paradoxically, they are a habitat for many commercially exploited species of high interest for society (Dimech et al., 2008). Despite the uncertainty of how these communities might respond to protection, we have to begin by designing conservative actions for these ecosystems and identifying areas within commercially exploited fishing grounds that could be permanently closed to trawling. Each situation must be carefully analysed, including the size of the protected area, the effort allocation, and the ecological connectivity between areas (Roberts et al., 2001), as an adequate network of MPAs should allow connectivity (Stelzenmuller et al., 2007). In this context, a small protected area in the middle of a fishing ground can be subjected to a limited recovery and still be highly influenced by fishing in the surroundings (as observed in our study). These areas should be large enough to provide a structured habitat and eliminate the negative influences of fishing from the nearby fishing grounds (Allison et al., 1998). With a proper design, the recovery time might be faster than expected. While the recovery of benthic fauna may take decades (Micheli et al,. 2004), we speculate from the observed results and, considering the abundance of sessile cnidarians inside a protected area established approximately 20 years ago, that the recovery of benthos might be faster than expected.

\section{ACKNOWLEDGEMENTS}

We thank all the participants in the Response project and on the Veda and Medes cruises. Mediterraneo Servicios Marinos, S.L. conducted side-scan sonar surveys at sea. Thanks are also due to S. Thrush for comments that improved this manuscript. This study was funded by the EU projects RESPONSE (Q5RS-2002-00787), AACC (EMPAFISH; CTM2007-29845-E/MAR) and COMSOM (CTM2008-04617/MAR).

\section{REFERENCES}

Allison, G., J. Lubchenco and M. Carr. - 1998. Marine reserves are necessary but not sufficient for marine conservation. Ecol. Appl., 8: 79-92.

Ardizzone, G. - 2006. An introduction to Sensitive and Essential Fish Habitats identification and protection in the Mediterranean Sea. Working Document to the STECF/SGMED-06-01 sub-group meeting on Sensitive and Essential Habitats in the Mediterranean, Rome.

Auster, P. - 2001. Defining Thresholds for Precautionary Habitat Management Actions in a Fisheries Context. N. Am. J. Fish.
Manage., 21: 1-9.

Auster, P. and R. Langton. - 1999. The effects of fishing on fish habitat. Am. Fish. Soc. Symp., 22: 150-187.

Bremner, J. and C. Frid and SI Rogers. - 2005. Biological traits of the North Sea benthos: does fishing affects benthic ecosystem function? In: P.T. Barnes, J.P. Thomas (eds.), Benthic Habitats and the Effects of Fishing, Am. Fish. Soc., 41: 477-489.

Bremner, J., S. Rogers and C. Frid. - 2003. Assessing functional diversity in marine benthic ecosystems: A comparison of approaches. Mar. Ecol. Prog. Ser., 254: 11-25.

Browman, H. and K. Stergiou. - 2004. Perspectives on ecosystembased approaches to the management of marine resources. Mar. Ecol. Prog. Ser., 274: 269-303.

Cacaud, P. - 2005. Fisheries laws and regulations in the Mediterranean: a comparative study. Studies and Reviews-General Fisheries Commission for the Mediterranean (FAO).

Clarke, K.R. - 1990. Comparisons of dominance curves. J. Exp. Mar. Biol. Ecol. 138: 143-157.

Clarke, K.R. and R.M. Warwick. - 1994. Changes in marine communities: an approach to statistical analysis and interpretation. Nat. Environ. Res. Counc., pp. 1-144, Plymouth, UK.

Collie, J., G. Escanero and P. Valentine. - 1997. Effects of bottom fishing on the benthic megafauna of Georges Bank. Mar. Ecol. Prog. Ser., 155: 159-172.

Dayton, P.K., S. Thrush, T. Agardy and R. Hofman. - 1995. Environmental effects of marine fishing. Aquat. Conserv., 5: 205-232.

de Juan, S., M. Demestre and S. Thrush. - 2009. Defining ecologi$\mathrm{cal}$ indicators of trawling disturbance when everywhere that can be fished is fished: A Mediterranean case study. Mar. Pol., 33: 472-478

de Juan, S., S. Thrush and M. Demestre. - 2007. Functional changes as indicators of trawling disturbance on a benthic community located in a fishing ground (NW Mediterranean Sea). Mar. Ecol. Prog. Ser., 334: 117-129.

Demestre, M. -2006. Response of benthic communities and sediment to different regimens of fishing disturbance in European coastal waters. Project final report: Q5RS-2002-00787, EU Project. ICM-CSIC, Barcelona.

Demestre, M., S. Juan, P. Sartor and A. Ligas. - 2008. Seasonal closures as a measure of trawling effort control in two Mediterranean trawling grounds: Effects on epibenthic communities. Mar. Pol. Bull., 56: 1765-1773.

Dimech, M, M. Camilleri, J.G. Hiddink, M.J. Kaiser, S. Ragonese and P.J. Schembri. - 2008. Differences in demersal community structure and biomass size spectra within and outside the Maltese Fishery Management Zone (FMZ). Sci. Mar. 724: 669-682.

Duineveld, G.C., M. Bergman and M.S. Lavaleye. - 2007. Effects of an area closed to fisheries on the composition of the benthic fauna in the southern North Sea. ICES J. Mar. Sci., 64: 899-908.

Ellingsen, K. - 2002. Soft-sediment benthic biodiversity on the continental shelf in relation to environmental variability. Mar. Ecol. Prog. Ser., 232: 15-27.

Ellis, J. and D. Schneider. - 1997. Evaluation of a gradient sampling design for environmental impact assessment. Environ. Monit. Assess., 48: 157-172.

Frid, C., O. Paramor and C. Scott,- 2005. Ecosystem-based fisheries management: progress in the NE Atlantic. Mar. Pol., 29: 461-469.

Friedlander, A.M., G.W. Boehlert, M.E. Field, J.E. Mason, J.V. Gardner and P. Dartnell. - 1999. Sidescan-sonar mapping of benthic trawl marks on the shelf and slope off Eureka, California. Fish. Bull., 97: 786-801.

Gray, J., P. Dayton, S. Thrush and M.J. Kaiser. - 2006. On effects of trawling, benthos and sampling design. Mar. Pol. Bull., 52: 840-843.

Hewitt, J.E., S. Thrush and V.J. Cummings. - 2001. Assessing environmental impacts: effects of spatial and temporal variability at likely impact scales. Ecol. Appl., 11: 1502-1516.

Hill, A., L. Veale, D. Pennington, S. Whyte, A. Brand and R. Hartnoll. - 1999. Changes in Irish Sea Benthos: Possible Effects of 40 years of Dredging. Estuar. Coast. Shelf Sci., 48: 739-750.

Jennings, S. and M.J. Kaiser. - 1998. The Effects of Fishing on Marine Ecosystems. Adv. Mar. Biol., 34: 201-352.

Jennings, S., M.D. Nicholson, T.A. Dinmore and J.E. Lancaster. 2002. Effects of chronic trawling disturbance on the production of infaunal communities. Mar. Ecol. Prog. Ser., 243: 251-260. 
Jouffre, D. and C. Inejih. - 2005. Assessing the impact of fisheries on demersal fish assemblages of the Mauritanian continental shelf, 1987-1999, using dominance curves. ICES J. Mar. Sci., 62: 380-383

Kaiser, M., K. Clarke, H. Hinz, M. Austen, P. Somerfield and I. Karakassis. - 2006. Global analysis of response and recovery of benthic biota to fishing. Mar. Ecol. Prog. Ser., 311: 1-14.

Lohrer, A.M., S.F. Thrush and M. Gibbs. - 2004. Bioturbators enhance ecosystem function through complex biogeochemical interactions. Nature, 431: 1092-1095.

Machias, A., V. Vassilopoulou, D. Vatsos, P. Bekas, A. Kallianiotis, C. Papaconstantinou and N. Tsimenides. - 2001. Bottom trawl discards in the northeastern Mediterranean Sea. Fish. Res., 53: 181-195.

Krost, P., M. Bernhard, F. Werner and W. Hukriede. - 1990. Otter trawl tracks in Kiel Bay (Western Baltic) mapped by side-scan sonar. Meeresforschung / Rep. Mar. Res. 32: 344-353.

Micheli, F., B.S. Halpern, L.W. Botsford and R.R. Warner. - 2004. Trajectories and correlates of community change in no-take marine reserves. Ecol. Appl., 14: 1709-1723.

Ojeda-Martínez, C., F. Giménez, J. Bayle-Sempere, C. Barbera, C. Valle, J. Sanchez-Lizaso, A. Forcada, P. Sanchez-Jerez, P. Martín-Sosa and J. Falcón. - 2009. A conceptual framework for the integral management of marine protected areas. Ocean Coast. Manag., 52: 89-101.

Palanques, A., J. Guillen and P. Puig. - 2001. Impact of bottom trawling on water turbidity and muddy sediment of an unfished continental shelf. Limn. Oceanog., 46: 1100-1110.

Papaconstantinou, C. and H. Farrugio. - 2000. Fisheries in the Mediterranean. Med. Mar. Sci., 1: 5-18.

Pearson, T. - 2001. Functional group ecology in soft-sediment marine benthos: the role of bioturbation. Oceanogr. Mar. Biol. Апnи. Rev., 39: 233-267.

Pipitone, C., F. Badalamenti, G. D'Anna and B. Patti. - 2000. Fish biomass increase after a four-year trawl ban in the Gulf of Castellammare (NW Sicily, Mediterranean Sea). Fish. Res., 48: $23-30$.

Queirós, A.M., J.G. Hiddink, M.J. Kaiser and H. Hinz. - 2006. Effects of chronic bottom trawling disturbance on benthic biomass, production and size spectra in different habitats. J. Exp. Mar. Biol. Ecol., 335: 91-103.

Rees, S.E., M.J. Attrill, M.C. Austen, S.C. Mangi, J.P. Richards and L.D. Rodwell. - 2010. Is there a win-win scenario for marine nature conservation? A case study of Lyme Bay, England. Ocean Coast. Manag., 53: 135-145.

Roberts, C.M, J.A. Bohnsack, F. Gell, J.P. Hawkins and R. Goodbridge. -2001 . Effects of marine reserves on adjacent fisheries. Science, 294: 1920-1923.

Sanchez-Lizaso, J. and J. Lleonart. - 2002. Actas del VII Foro científico para la pesca española en el Mediterráneo. In: Universitario EC (ed.), pp. 137. Alicante, Spain.

Sanchez, P., M. Demestre, M. Ramon and M.J. Kaiser. - 2000. The impact of otter trawling on mud communities in the northwestern Mediterranean. ICES J. Mar. Sci., 57: 1352-1358.

Sanchez, P., P. Sartor, L. Recasens, A. Ligas, J. Martin, S. De Ranieri and M. Demestre. - 2007. Trawl catch composition during different fishing intensity periods in two Mediterranean demersal fishing grounds. Sci. Mar., 71: 765-773.

Sartor, P., J. Martin, A. De Biasi, L. Recasens, B. Reale, J. Cartes, S. de Juan, S. De Ranieri and M. Demestre. - 2007. Trawling effort estimation in two fishing grounds from the central and NW Mediterranean: direct v indirect methodologies. In: CIESM (ed). 38 Rapp. Comm. Int. Mer. Medit., Istambul.

Smith, C.J., K.N. Papadopoulou and S. Diliberto. - 2000. Impact of otter trawling on an eastern Mediterranean commercial trawl fishing ground. ICES J. Mar. Sci., 57: 1340-1351.

Stelzenmuller, V., F. Maynou and P. Martin. - 2007. Spatial assessment of benefits of a coastal Mediterranean Marine Protected Area. Biol. Conserv., 136: 571-583.

Thrush, S.F. and P.K. Dayton. - 2002. Disturbance to marine benthic habitats by trawling and dredging: Implications for Marine Biodiversity. Annu. Rev. Ecol. Sys., 33: 449-473.

Thrush, S. and P. Dayton. - 2010. What can ecology contribute to Ecosystem-Based Management? Annu. Rev. Mar. Sci., 2: 419-441.

Thrush, S., J. Hewitt, V. Cummings, P. Dayton, M. Cryer and S. Turner. - 1998. Disturbance of the marine benthic habitat by commercial fishing: impacts at the scale of the fishery. Ecol. Appl., 8: 866-879.

Thrush, S., J. Halliday, J.E. Hewitt and A.M. Lohrer. - 2008. The effects of habitat loss, fragmentation, and community homogenization on resilience in estuaries. Ecol. Appl., 18: 12-21.

Tillin, H.M., J.G. Hiddink, J. Jennings and M.J. Kaiser. - 2006. Chronic bottom trawling alters the functional composition of benthic invertebrate communities on a sea-basin scale. Mar. Ecol. Prog. Ser., 318: 31-45.

Veale, L., A. Hill, S. Hawkins and A. Brand. - 2000. Effects of long-term physical disturbance by commercial scallop fishing on subtidal epifaunal assemblages and habitats. Mar. Biol., 137: 325-337.

Widdicombe, S., M.C. Austen, M.A. Kendall, R.M. Warwick and M.B. Jones. -2000 . Bioturbation as a mechanism for setting and maintaining levels of diversity in subtidal macrobenthic communities. Hydrobiologia, 440: 369-377.

Scient. ed.: V. Stelzenmuller.

Received October 8, 2010. Accepted January 21, 2011

Published online April 27, 2011. 